VOL. 03 NO. 02 , DECEMBER 2021

\title{
OBSTACLES AND SOLUTION TOWARD ENGLISH LEARNING DURING COVID-19 PANDEMIC
}

\author{
Erlinda Sonya Pale \\ Universitas Timor \\ Erlinda_pale@yahoo.com
}

\begin{abstract}
The process of online English learning during covid-19 pandemic brings both positive and negative impact. The positive impact could support learners to learn better. On the other side, the negative impacts could worsen the learning process. The present study was managed in order to answer three research questions mentioned as the problems faced by students and lecturers during English online learning in the pandemic of covid - 19, the most problem took place, and to find out possible solution to deal with the issue. The method implemented in this study was qualitative method with questionnaire and open-ended interview as the instruments. The result of the study pinpointed that atrocious internet was the problem occurred mostly during English online learning. The possible solution such as being focus in online learning, find places with good network, earlier material delivery and self-motivation were proposed by the students. Implementing blended learning was the solution recommended by the lecturers. To sum up, the obstacles in online English learning should be identified in order to be utilized as an input for the improvement of the learning process itself. Furthermore, the solutions could also become the factors to be considered as ways to enhance the process of English online learning.
\end{abstract}

Keywords: English online learning, covid 19 pandemic, obstacles and solution.

\section{INTRODUCTION}

The effect of covid -19 goes through all aspects of human's life. Economy, health and education are three aspects of life which experience the most impact of the virus (Nuraeni, 2021; Osman, 2020). Furthermore, psychological and social aspects also get the impact of this virus (Bostan et al., 2020). Since the end of 2019, the existence of this virus has been reported to bring huge impact on human's life in all elements of life. This is because the way of spreading of this virus triggers all activities to be carried out without direct contact, included education.

The normal process of learning which was used to run through face to face interaction has been changed to an online system (Abidah et al., 2020). This is carried out as an effort to minimize the spread of the virus as direct contact among people will increase the spread of this virus. Schools have to be closed as direct contact among students and teachers could worsen the spread of the virus. In addition, the areas of schools are the places where a crowded of people meet and interact each other. Therefore, the risk of getting infectious will be higher (Sintema, 2020).

The change of learning process from face to face interaction into online learning does not run smoothly. A number of factors causes the online learning not to be conducted effectively, especially in Indonesia. This is because education in Indonesia is still considering that face to face interaction is a good way in teaching and learning process. It is considered that the real education in Indonesia could occur only if a teacher and learners have face to face interaction (Fitria, 2020). People think that online class has no benefit for education. Moreover, students usually face problems such as network issues which lead to not focusing during teaching and learning process, as well as lack of internet packages. The presence of this virus forces educational institutions to be creative in finding out solutions in order to keep learning process stays run smoothly. However, it is not an easy task to do as students and teachers in Indonesia has been exposed to education through face-to-face interaction in a long period of time.

As previously stated, that all educational institutions have to be conducted online as a step to reduce the spread of covid - 19. This condition triggers teachers to apply online learning or what is known as school from home. Several online learning platforms such as google classroom, google meet, zoom, video conference have 


\section{VOL. 03 NO. 02 , DECEMBER 2021}

been implemented by teachers to assist them. Moreover, social medias such as Facebooks, Messenger, and WhatsApp are also utilized for supporting online learning.

The process of teaching and learning during the pandemic of covid-19 has to be carried out without close contact, included in Timor University (TU). As the only public university at the border of Republic Democrat Timor Leste, the spread of covid-19 also enters this place, forcing the university to implement online learning. On the contrary, some obstacles have been spotted and they bring negative impacts on the learning process.

Based on the researchers' observation in English department, it was found out that learners usually have problems in the case of internet network and internet packages. Some students rarely enter classroom because of these issues. This condition sometimes minimizes the learners' motivation to study. When lecturers give them assignment to be submitted online, the learners complain that they are running out of internet packages that they ask for additional time for handed in their works, while waiting for money from their parents or relatives. Government has provided internet packages for the students to solve their problem. On the other hand, the students also said that those packages are not enough to fulfill their learning needs. Furthermore, several students complain that they have no laptop or phone to assist them in online learning.

In addition, since the starting point of the existence of covid-19, some researchers have carried out studies deals with this virus. Abidah et al (2020) researched on the impact of covid-19 to Indonesian education and its relation to the philosophy of Merdeka Belajar (MB). This study is a type of position paper to persuade readers. This paper presents some basic points mentioned as the philosophy of MB, ways to prevent covid-19, and digital learning during covid-19. The next study was researched by Sintema (2020) which examined the effect of covid19 on the performance of grade 12 students in secondary schools in Zambia. The data was obtained from tree teachers at a public secondary school. The instrument used for carrying out this research was a semi structured interview. The finding affirmed that there is a reducing in the percentage of pass for national examination due to covid-19. The study of Oman (2020) scrutinized the impact of the pandemic generally on the Sultanate of Oman and particularly on educational system. Furthermore, it is also equipped with an analytic description of the university involvement and lesson learned from the impact of the pandemic on the changing of teaching and learning landscape.

In accordance with the facts shown above, the current study is performed to answer three fundamental issues mentioned as what are obstacles in teaching and learning English during the pandemic of covid-19, what is the most obstacle found in teaching and learning of English during the pandemic of covid-19, and what are possible solutions to overcome those obstructions.

\section{METHOD}

\section{Respondents}

There are 45 students and 5 lecturers of English department of Universitas Timor participated in the current study. A set of questionnaires was delivered to the subject of the study to be completed. In addition, an open - ended interview was carried out to the participants to find more required data.

\section{Instruments}

A set of questionnaires as well as an open - ended interview were the instruments which assisted the process of obtaining the data. The questionnaire was handed over to the students and lecturers in different days. After working on the questionnaire, twenty students and five lecturers were interviewed in five days respectively, the students were interviewed for four days, and the last day was to find more information from the lecturers. The questionnaire comprises two questions mentioned as: what obstacles do you find in learning English during covid - 19 pandemics, and what is the possible solution to deal with the obstacles you encountered. The open-ended interview was to seek deeply more information which could support the data gained from the questionnaire.

\section{Procedures}

The present study was executed by implementing qualitative method by delivering questionnaire to the subject of the study. The subject of the study were the students of English Department students of Timor University as well as their lecturers. The subject of the study were asked to answer questions which were used as 


\section{VOL. 03 NO. 02 , DECEMBER 2021}

sources of data. The data then be analysed to figure out the most factors affecting learning process in the pandemic of covid-19 and to discover possible solutions to cope with the obstructions.

The research was commenced by handing over the questionnaire to the students and lecturers in different days. After working on the questionnaire, twenty students and five lecturers were interviewed in five days respectively, the students were interviewed for four days, and the last day was to find more information from the lecturers. The data from the questionnaire and interview were then placed in several themes in order to make the process of analyzing becomes straightforward.

\section{Data Analysis}

In the process of analyzing the data, the answers which were gathered from the questionnaire as well as the interview were settled in two different themes mentioned as common issues and specific issues. Furthermore, the researcher also separated the answers provided by the students and the lecturers. After putting the result in two different themes, the researcher put a closer look on the result and relate the data to answer the three research questions as stated in the previous session. With regard to this, the researcher also transcribed the result of the interview and distributed them to the participants of the study to ask for confirmation. As stated by Kumar (2011), "Validation of the information by a respondent is an important aspect of ensuring the accuracy of data collected through unstructured interviews." By asking for confirmation and approval from the participants of the study, the data obtained will be valid since it promotes accurateness. The last step to be executed was to present and describe the data. The data were displayed in form of figure and table, followed by brief description in order to address the research questions. The description of the data was put in order to address each research question, commenced from the first to the third research question.

\section{FINDINGS AND DISCUSSION}

The result of the study answers three main issues which have been listed in the following section.

\section{Obstacles in Teaching and Learning English During the Pandemic of Covid-19}

There is a wide variety of obstacles found in English online learning during covid-19 pandemic. Those obstacles come from general issues up to the specific ones, that is factor coming from the students themselves. Bad internet connection and internet packages are general components encountered by all of the students while factors such as less understanding of material, less focus and difficulties in carrying out tasks are the aspects which are considered as internal factors. Interestingly, the students still complain about the same problem they have while going through offline learning, that is the number of tasks given by their lecturers. Even with smaller portion, that issue still becomes their difficulties during the implementation of online learning. The product of the present study is in line with the other study which mentioned that unstable network is one problem found in online learning (Asha, 2021).

In order to provide a clear description, those obstacles are set in the figure to follow.

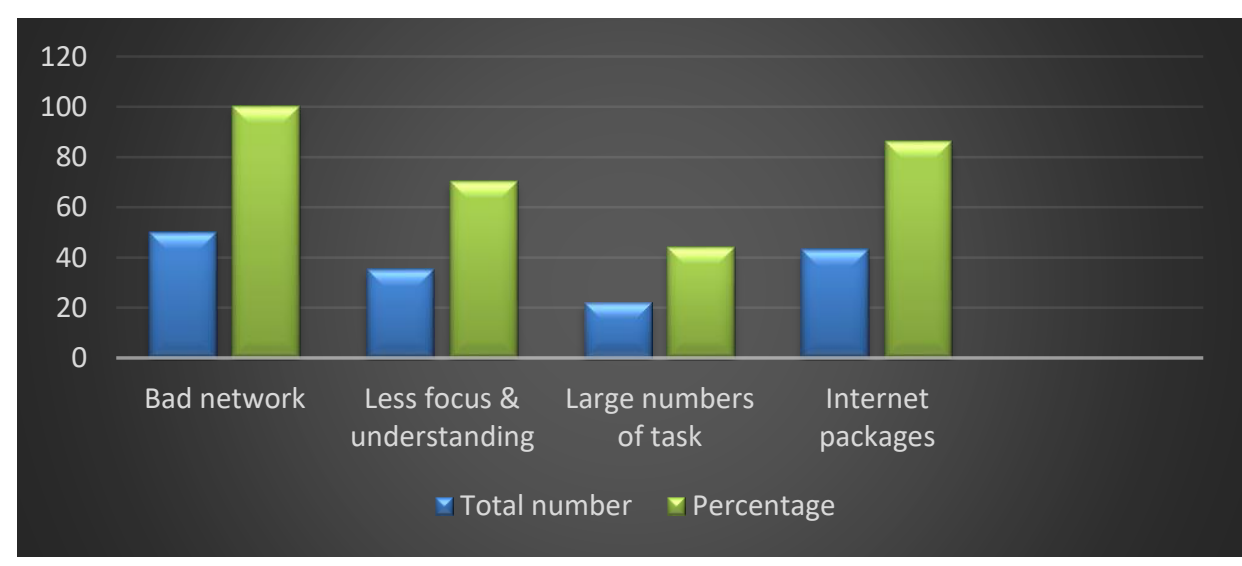


Figure 1. Students' obstacles in online learning English

From the lecturers' point of view, students' motivation and poor attention during online learning were the problems which existed. Moreover, lecturers also claimed that they required extra time to prepare for the material to be taught as online learning requires them to be more creative. The aspect of students' achievement could also be affected by online learning. In addition, character education, trustworthiness between lecturers and learners as well as negative effect of the students' psychomotor are also the impact of English online learning. System evaluation is also another repercussion of online learning. In the teaching and learning of English especially the teaching of speaking, the students have to practice a lot. On the other side, online learning impeded the students to do such thing. The following table illustrates more on the data.

Table 1. Lecturers' obstacles in online teaching English

\begin{tabular}{|c|c|c|c|}
\hline No & Obstacle & Number & Percentage (\%) \\
\hline 1 & Diminish the students' achievement & 5 & 100 \\
\hline 2 & Lack of control towards the students' education character & 3 & 60 \\
\hline 3 & Lack of trustworthiness & 4 & 80 \\
\hline 4 & Bring negative impact on the students' psychomotor & 2 & 40 \\
\hline 5 & Bring difficulties in evaluation system & 5 & 100 \\
\hline 6 & Dreadful internet connection & 5 & 100 \\
\hline
\end{tabular}

However, the finding of other study does not include psychological factors as problems found in online learning (Asha, 2021). This study focuses merely on casual components such as lack of facility, bad network, minimum communication between teachers and students, insufficient parental care, limitation of students' learning strategies and a large number of tasks by teachers or lecturers. The other study implemented library research in order to find obstacles found in education in the midst of covid-19 pandemic. Problems such as readiness of the students and lack of human resources were found. The researcher then recommended that there should be a good cooperation between region and central government to fix the problems (Batubara, 2021). Students also need to be focus during online learning to maximize their learning process since their attention could also impede the effectiveness in online learning (Dhawan, 2020).

\section{The Most Obstacle Found in Teaching and Learning English During Covid 19 Pandemic}

Dreadful internet connection is the most issue which are faced by both the students and the lecturers in the process of teaching and learning English during the pandemic. All the students have this kind of problem while having online learning. Moreover, the students live in places with very low quality of internet. This is, as previously stated, dealt with common aspect where the students could not control. The same trouble was also experienced by the lecturers which have been presented in the previous session.

\section{Possible Solutions to Cope with Those Issues}

Referred to the questionnaire which have been distributed as well as the outcome of the interview, some solutions towards the existing problems being presented. Those solutions were coming from the students and the lecturers. A wide variety of the students' answer was appeared. The solutions were settled into two essential components mentioned as solution from students' point of view (SPV) and lecturers' point of view (LPV). Being focus in using online application, find places with good internet connection, concentrate more on the topic being taught, build good communication between students and lecturers, use less package online learning platform such as WhatsApp, being respect to each other, and being discipline are listed solutions from SPV. The students also suggest their lecturers to become strict in the learning process, give detail explanation, and deliver material earlier. On the other hand, lecturers suggest to run blended learning in order to decrease detrimental effects of online 
learning. As put forward by other study, interaction is the main point to determine the success of online learning (Dhawan, 2020). Consequently, lecturers and students have to work together to maintain a good interaction during the online learning. One way to keep up the good interaction is by using various online teaching media in a meeting. To illustrate, while having online learning in zoom, the students and lecturers could also communicate in WhatsApp.

The product of the present study could be followed up by next study to focus on more solutions to deal with problems in online learning. It seems that online learning would not be ceased here. The pandemic of covid19 is the starting point of online learning to be run globally. Previously, online learning has been carrying out by other countries. On the other hand, it is conducted all over the world by reason of the emerge of covid-19. Therefore, more solution is required by all educational institutions to make online learning to be successful.

\section{CONCLUSION AND SUGGESTION}

The problems faced by the students and lecturers during English online learning ranges from common issues up to the specific ones. The common problems dealing with dreadful internet connection as well as lack of internet packages. Lack of focus and understanding and large number of tasks are also the issues encountered by the students in English online learning. The lecturers propose idea to implement blended learning to support English online learning. Being focus during learning process and self -reflection are recommended by the students to reinforce learning process. Furthermore, it is expected for later studies to emphasize more on efforts to support the accomplishment of online learning.

\section{REFERENCES}

Abidah, A., Hidaayatullaah, H. N., Simamora, R. M., Fehabutar, D., \& Mutakinati, L. (2020). The impact of covid-19 to Indonesian education and its relation to the philosophy of "Merdeka Belajar." Studies in Philosophy of Science and Education, 1(1), 38-49. https://doi.org/10.46627/sipose.v1i1.9

Asha, L. (2021). Online learning problems and the principal's efforts to overcome the problems. AL-ISHLAH: Jurnal Pendidikan, 13(2), 1247-1258. https://doi.org/10.35445/alishlah.v13i2.932

Batubara, B. M. (2021). The Problems of the world of education in the middle of the Covid19 pandemic. Budapest International Research and Critics Institute (BIRCI-Journal): Humanities and Social Sciences, 4(1), 450-457. https://doi.org/10.33258/birci.v4i1.1626

Bostan, S., Erdem, R., Öztürk, Y. E., Kılıç, T., \& Y1lmaz, A. (2020). The effect of covid-19 pandemic on the Turkish society. Electronic Journal of General Medicine, 17(6). https://doi.org/10.29333/ejgm/7944

Dhawan, S. (2020). Online learning: A panacea in the time of Covid-19 crisis. Journal of Educational Technology Systems, 49(1), 5-22. https://doi.org/10.1177/0047239520934018

Fitria, T. N. (2020). Teaching English through online learning system during covid-19 pandemic. Pedagogy: Journal of English Language Teaching, 8(2), 138. https://doi.org/10.32332/pedagogy.v8i2.2266 
Kumar, R. (2011). Research Methodology: A step-by step guide for beginners. New Delhi: SAGE Publications India Pvt Ltd.

Nuraeni, C. (2021). Maximizing mobile-assisted language learning ( MALL ) amid covid- 19 pandemic : Teachers 'perception. 5(1), 11-18.

https://doi.org/10.31002/metathesis.v5i1.3336

Osman, M. E. T. (2020). Global impact of covid-19 on education systems: the emergency remote teaching at Sultan Qaboos University. Journal of Education for Teaching, 46(4), 463-471. https://doi.org/10.1080/02607476.2020.1802583

Sintema, E. J. (2020). Effect of COVID-19 on the performance of grade 12 students: Implications for STEM education. Eurasia Journal of Mathematics, Science and Technology Education, 16(7), 1-6. https://doi.org/10.29333/EJMSTE/7893 